\title{
THE DAMNING EFFECT OF TERRORISM ON THE ENVIRONMENT: TOWARDS A SUSTAINABLE INTERNATIONAL LEGAL FRAMEWORK
}

\author{
Eisa Al-Enezy*
}

\begin{abstract}
The increasing spate of terrorist activities and its damning effect on the environment through the use of harmful explosive devices calls for a comprehensive study to examine the need for an international legal framework for environmental protection. This paper examines terrorist activities and counter-terror measures and the transboundary pollution effect of such measures in an increasingly populated planet. While adopting an analytical legal research method, this study analyses the environmental effect of terrorism and counter-terror measures using notable terrorist activities such as the 9/11 attack on the United States and relevant international legal instruments promulgated to combat terrorism and its harmful environmental effects. The article concludes that while the act of terrorism should be condemned by all as it is harmful to the environment, counter-terror measures should be well managed to avoid environmental degradation and human collateral damage. An international legal framework will be required to drastically reduce the environmental effect of counter-terror measures.
\end{abstract}

Keywords: transboundary pollution, terrorism, counter-terror measures, environmental degradation

Dr. Eisa Al-Enezy is an Associate Professor and Head of Department of International Law, Faculty of Law, Kuwait University. 


\title{
KESAN DAHSYAT KEGANASAN KE ATAS ALAM SEKITAR: KE ARAH KERANGKA PERUNDANGAN ANTARABANGSA YANG LESTARI
}

\begin{abstract}
ABSTRAK
Peningkatan kejadian aktiviti keganasan dan kesannya yang dahsyat ke atas alam sekitar melalui penggunaan bahan letupan yang bahaya memanggil kepada satu kajian menyeluruh bagi mengkaji keperluan satu kerangka perundangan antarabangsa untuk perlindungan alam sekitar. Makalah ini mengkaji aktiviti pengganas dan langkahlangkah menentang keganasan dan kesan pencemaran merentas sempadan akibat dari langkah-langkah tersebut dalam keadaan populasi planet yang kian meningkat. Menerusi metod analisa penyelidikan perundangan, kajian ini menganalisa kesan kepada alam sekitar daripada keganasan dan langkah-langkah menentang keganasan menggunakan aktiviti keganasan yang ketara seperti serangan 9/11 ke atas Amerika Syarikat. Kajian ini juga meneliti instrumen perundangan antarabangsa relevan yang dimasyhurkan untuk menentang kegansan dan kesan bahayanya ke atas alam sekitar. Makalah ini menyimpulkan bahawa walaupun tindakan keganasan harus dikutuk oleh semua kerana mengakibatkan kesan bahaya ke atas alam sekitar, langkah-langkah menentang keganasan harus di uruskan dengan baik bagi mengelakkan degradasi alam sekitar dan kerosakan sampingan ke atas manusia. Satu kerangka perundangan antarabangsa perlu diwujudkan untuk menurunkan secara drastik kesan langkah-langkah menentang keganasan ke atas alam sekitar.
\end{abstract}

Kata Kunci: pencemaran merentas sempadan, keganasan, langkah-langkah menentang keganasan, degradasi alam sekitar

\section{INTRODUCTION: REVISITING THE MEANING OF TERRORISM}

Terrorist activities can take place anywhere in the world, and as witnessed in the past decade, no country seems to be safe from 
terrorist attacks. Previous terrorist attacks have led to several causalities, economic loss, infrastructural degradation, and environmental destruction in different forms. It is thus clear that terrorism is not limited to a particular colour, religion or race. What triggered the current anti-terror measures was the gruesome attacks in 2001 that hit both New York and Washington DC. ${ }^{1}$ Since that attack, the international community have come together to introduce a number of international legal instruments to combat the increasing spate of terrorist attacks. Whether these measures have been successful or not, particularly from the environmental perspective, is an issue that should be explored further.

The traditional failure of the fight against terrorism and the kinds of weapons of mass destruction in the hands of the terrorist groups raise the questions whether the existing legal regime for fighting terrorism is adequate, and whether the environment is secured enough in the fight against terrorism. In addressing these questions, it is pertinent to revisit the definition of terrorism because, "[e]fforts to define terrorism under international law have been going on for a long time. [...] Yet, despite 15 U.N. conventions ${ }^{2}$ and two draft conventions dealing with various aspects of terrorism - including

The Twin Towers: The Last Moments, N.Y. Post, Sept. 12, 2001, available at 2001 WL 26051623;Micheal Grunwald, "Terrorists Hijack 4 Airliners, Destroy World Trade Center, Hit Pentagon; Hundreds Dead," The Washington Post, accessed December 19, 2015, http://www.washingtonpost.com/wpdyn/content/article/2001/09/12/AR2005033107980.html; David Willman Alan C. Miller, "Watch List' Didn't Get to Airline - Latimes," Los Angeles Times, accessed December 19, 2015, http://articles.latimes.com/2001/sep/20/news/mn47824.

2 League of Nations, Convention for the Prevention and Punishment of Terrorism, O.J. 19 at 23 (1938); League of Nations Doc. C.546(I). M.383 (I) 1937V (1938), International Convention Against the Taking of Hostages, U.N. GA Res. 34/154 (XXXIV), U.N. GAOR, 34 Sess., Supp. No. 46 at 245, U.N. Doc. A/34/146 (1979), International Convention for the Suppression of Terrorism bombings, G.A. Res. 165, U.N. GAOR, 52 Sess, U.N. Doc. A/52/164 (1998), Convention on the Prevention and Punishment of Crimes Against Internationally Protected Persons, Including Diplomatic Agents, opened for signature Dec. 14, 1973, 1035 U.N.T.S. 167; Convention on the Safety of United Nations and Associated Personnel, G.A. Res. 59, U.N. GAOR, 49th Sess., U.N. Doc. A/49/59 (1994), Convention to Prevent and Punish Acts of Terrorism Taking the Form of Crimes Against Persons and Related Extortion that are of International Significance, O.A.S. Doc. A/6/Doc. 88 rev. 1, corr.1 (Feb. 2, 1971), Draft Convention for the Suppression of Acts of Nuclear Terrorism, U.N. Doc. A/C.6/53/L.4 (1998), and European Council, European Convention on the Suppression of Terrorism, Europ. T.S. No. 90, (Jan .27, 1997). 
hijacking, bombing, piracy, assassination, hostage taking, and biological, chemical and nuclear warfare - the international community has yet to settle on a single definition of "terrorism"."3

The absence of such settlement can be attributed to the difference of ideologies, ethical values, and religions that member States of the U.N. use as a pretext to oppose any definition affecting their political goals. Based on the culture, background, or the misinterpreted religious orders, the definition of terrorism may be varied. As such, an act may considered as a terrorist act in one part of the world may be interpreted as an act of heroism in another part. Therefore, terrorism can be defined within the context of domestic and foreign affairs of a particular state depending on the foreign policies of such a state.. ${ }^{4}$ For example, some Muslim and Arab nations view suicide bombing in Israel as acts of heroism; meanwhile, Israel and most of the western countries consider such acts as terrorism. Similarly, Israeli attacks, under the pretext of self-defense, against Hizbollah Guerrilla bases in South Lebanon are considered by many Muslim and Arab nations as acts of terrorism; however, such attacks are interpreted by Israel and some western countries as a right of selfdefence.

This difference could almost disappear if such actions take place within a regional organisation that assembles similar, if not identical, ideologies, ethical values and religious background under a single umbrella such as the Organisation of Islamic Cooperation (OIC). Therefore, The OIC successfully defined terrorism in its own unique way. For example, Article 1 (2) of the Convention of the Organization of the Islamic Conference (OIC) on Combating International Terrorism of $1999,{ }^{5}$ defines terrorism as any act of violence or threat thereof not withstanding its motives or intentions perpetrated to carry out an individual or collective criminal plan with the aim of terrorizing people or threatening to harm them or imperiling their

3 Cherif Bassiouni interviewed by Williams C. Smith, "Legal Arsenal: International Law Can Be An Important Element in the United States' Campaign Against Terrorism," American Bar Association Journal 87 (2001): 42.

4 Yonah Alexander, "Terrorism in the Twenty-First Century: Threats and Responses," DePaul Bus. LJ 12 (1999): 59.

5 Convention of the Organization of the Islamic Conference on Combating International Terrorism, Jul. 1, 1999, Ouagadougou, in International Instruments Related to the Prevention and Suppression of International Terrorism, (United Nations Publication, 2001) Sales No. E.01.V.3, at 187. 
lives, honor, freedoms, security or rights or exposing the environment or any facility or public or private property to hazards or occupying or seizing them, or endangering a national resource, or international facilities, or threatening the stability, territorial integrity, political unity or sovereignty of independent States.

This definition has a broad scope as it includes a wide range of issues, including exposing the environment to hazards through whatever means. This justifies the increasing need for the consideration of the environmental dimensions of acts of terrorism and the increasingly sophisticated anti-terror war.

\section{ENVIRONMENTAL DIMENSIONS IN THE DEFINITION OF TERRORISM}

In a remarkable step, the OIC, besides defining the terrorism, includes the act of exposing the environment to hazards as act of terrorism. In general, defining the terrorism in domestic law also does not raise the question of ideological, ethic, or religious differences. The Department of Defense (DoD) defines the terrorism as "the calculated use of violence or the threat of violence to inculcate fear; intended to coerce or to intimidate governments or societies in the pursuit of goals that are generally political, religious, or ideological.,"

Acts of terrorism can take place by hijacking planes, destroy building by using conventional techniques such as explosions, use arms of mass destruction, killing innocent people, deliberately polluting natural resources, or threatening to commit any of these acts. ${ }^{7}$ It is notable that most of the definitions agree on the same elements to describe an act as terrorism. Both the effective harms and threat to affecting human lives and the environment are considered as acts of terrorism, where a real and effective harm occurred within the U.S., buildings were demolished, human lives were ended, and the natural environment was polluted. In "November, 1977, the Federal Bureau of Investigation (FBI) confirmed an extortionist threat to place a deadly botulism poison in the Miami, Florida, water supply

6 The Terrorism Research Center, The Basics of Terrorism: Part 1, 1997, accessed December 19, 2015 http://www.terrorism.com/terrorism/bpart1.html.

7 B Hoffman and K Riley, "Domestic Terrorism: A National Assessment of State and Local Preparedness" (Santa Monica: RAND, 1995). 
unless a demand for a 1.6 million dollar payment was met." ${ }^{8}$ Another example is the threats, issued by Al-Qaeda spokesman after the events of September $11^{\text {th }}$, of targeting Americans and Jewish, hijacking more planes and the destroying more high buildings, possible using of weapons of mass destruction. ${ }^{9}$ These threats can stand alone as acts of terrorism by themselves.

There is no legal difference between committing an act of terrorism and the threat to commit such act, where both are subject to the same rules, produce fearful among the nation and cause considerable economic losses. The preventive measures took by the American authorities cost the country considerable amounts of money. ${ }^{10}$ However, environmentally, the difference between the effective terrorism and the threat of terrorism is that both human beings and the environment are the victims of an actual act of terrorism.. On the other hand, when there is only a threat of terrorist act, the fear and horror will only affect the population; there will be no harm to the environment.

The need for international efforts to adopt an accepted definition for terrorism and intensive international procedures to fight the terror was significantly increased after the events of September 11. These efforts should have been put in place long ago, especially after the collapse of the former Soviet Union, which had a sophisticated arms that have been exposed in the black market. ${ }^{11}$ Terrorists were the frequent customers of this market. And terrorists increasingly became "interested in mass destruction," 12 which was, and remains, a real threat to human life and the environment. For long time, the

8 Robert A Friedlander, Terror-Violence: Aspects of Social Control (Oceana Publications, 1983), 147.

9 "CNN.com - Video Warns of More Terror Attacks - October 10, 2001," accessed December 19, 2015, http://edition.cnn.com/2001/WORLD/asiapcf/central/10/10/gen.alqaeda.video/in dex.html.

10 Before September 11th terrorist acts, the United States used to spend \$7 billion to fight the terrorism. See John Diamond, "Use of Anti Terror Funds Hard to Track, US Auditors Find," Boston Globe, September 1998.

11 Ashton B Carter, "Reducing the Nuclear Dangers from the Former Soviet Union," Arms Control Today 22, no. 1 (1992): 10; Barry L Rothberg, "Averting Armageddon: Preventing Nuclear Terrorism in the United States," Duke J. Comp. \& Int'l L. 8 (1997): 97.

12 Stefan H Leader, "The Rise of Terrorism," Security Management 41, no. 4 (1997): 34-39. 
international community neglected the threat of terrorism, which increased the effect that terrorist groups may cause to human life and the environment. For example, a number of incidents took place in the last few years, and were very fearful, such as the Oklahoma City bombing of $1995,{ }^{13}$ the Tokyo Subway Sarin gas attack in $1995,{ }^{14}$ the detonation of the American Navy Warship in Yemen in October 12, $2000,{ }^{15}$ the terrorist attacks of the World Trade Center (WTC) in New York and the Pentagon in Washington D.C. on September 11, $2001 .^{16}$

\section{THE ENVIRONMENTAL EFFECTS OF TERRORIST ATTACKS}

The destruction of environment in any terrorist act or in an anti-terror military engagement has far-reaching effects of the ecosystem and both acts paint a malicious picture of terrorism. Therefore, the examination of the environmental effects of terrorism in this paper will focus on both the environmental view, which includes humans as part of the environment, and any destruction to the environment. Most of terrorist activities affect at the same time humans and the environment, especially when terrorists use sophisticated arms that may cause widespread, long-lasting or severe environmental harm.

Nowadays, "terrorist weaponry has not been limited merely to guns and explosive devices," ${ }^{17}$ since the hands of terrorists now reach modern technology, such as Depleted Uranium (DU), chemical and biological devices. "[T]he House of Representatives Internal Security Subcommittee investigated the DoD's policy of surplus explosives, and found that 26 million pounds have been sold to commercial applicants with almost no controls exerted over the sale. Apparently, some of these explosives have already found their way into the hands

13 Gavin Cameron, "Nuclear Terrorism: A Real Threat?," Janes Intelligence Review 8 (1996): 422-25.

14 Timothy Schofield, "The Environment as an Ideological Weapon: A Proposal to Criminalize Environmental Terrorism"(1999) 26," BC Envtl Aff L Rev 3, no. 26 (1999): 619.

15 Kevin Todd Shook, "State Sponsors of Terrorism Are Persons Too: The Flatow Mistake," Ohio St. LJ 61 (2000): 1301.

16 The Twin Towers: The Last Moments.

17 Friedlander, Terror-Violence: Aspects of Social Control, 141. 
of the U.S. domestic terrorists." ${ }^{18}$ Al-Qaeda is one of the terrorist groups that the American authorities believe they possess chemical and biological weapons. ${ }^{19}$ This theory was confirmed through samples taken from sites suspected to be terrorist laboratories. For example, sand samples taken from areas surrounding Al-Shifa facility in Sudan proved that lethal nerve agent VX and other chemical weapons components research were conducted in the facility. ${ }^{20}$ Another example is in November 2001, some military examination to certain caves, in Afghanistan, illustrated that researches were conducted by Al-Qaeda to produce chemical, biological, and even nuclear weapons. ${ }^{21}$ And finally, Osama Bin Laden, the leader of AlQaeda himself, threatened that his group possesses arms of mass destruction and he will retaliate over a possible American use of similar weapons. $^{22}$

In few cases, terrorist groups already used weapons of mass destruction. For example, the two attacks by Aum Shinrikyo the Japanese cult, involved chemical weapons unleashed through the use of modern technology. In the first case that occurred in 1994 in Matsumoto, in the central highlands of Honshu, Japan, nerve gas was used in a terrorist attack. This severely caused the death of seven civilians and injured dozens more. ${ }^{23}$ In 1995 , the second attacked took

18 Friedlander, Terror-Violence: Aspects of Social Control;Koziol, Pentagon Auctions of Explosives Pose a Terrorist Peril, Chicago Tribune, May 15, 1977, Sec. 2, Col.3 at 4.

19 "CNN.com - Bush Goes after Terrorists' Assets - September 25, 2001," accessed December 19, 2015, http://edition.cnn.com/2001/US/09/24/ inv.investigation.terrorism/.

20 Michael Barletta, "Chemical Weapons in the Sudan: Allegations and Evidence," The Nonproliferation Review 6, no. 1 (1998): 115-36.

21 "CNN.com - U.S. Tests for Chemical Weapons in Afghanistan - November 27, 2001," accessed December 19, 2015, http://edition.cnn.com/2001/WORLD/ asiapcf/central/11/27/ret.chemical.weapons/index.html.

22 "CNN.com - Nic Robertson: Bin Laden Interview - November 11, 2001," accessed December 19, 2015, http://edition.cnn.com/2001/WORLD/ asiapcf/central/11/11/ret.robertson.otsc/index.html.

23 Alan H. Lockwood, "The Public Health Effects of the Use of Chemical Weapons," in War and Public Health, ed. Barry S Levy and Victor W Sidel (American Public Health Association, 2000), 93.. 
place in the Tokyo subway, ${ }^{24}$ which caused twelve deaths ${ }^{25}$ and injured approximately 5,000 people. $^{26}$

Even if the terrorists do not use weapons of mass destruction, such dastardly attacks are still a threat to the human life and the environment. For instance, at least 23 people were killed and more than 300 others injured when it was alleged Al-Qaeda attacked an American establishment located in Al-Khobar, Saudi Arabia, in 1996, using a powerful truck bomb which tore through apartment buildings at U.S. Air Force complex. ${ }^{27}$ The effect of the explosion was so much to the extent that a crater 35 feet deep and 85 feet across were blasted away. ${ }^{28}$ The United States as well as Saudi Arabia suffered numerous casualties. $^{29}$

Another example is Al-Qaeda's attack of October 12, 2000, against the American Navy's Warship USS Cole in the Gulf of Aden, Yemen. The explosion caused various human causalities when seventeen United States Navy sailors were killed, while further causing devastating environmental harm to the Gulf itself. Nevertheless, the involved countries and the international community ignored the environmental damage that resulted from such explosion to the marine environment of the Gulf of Aden, its ground, and marine lives. And there is no assessment to be used against the terrorists for their crimes against the environment. Further examples may be found in the massive environmental damage experienced in the September 11 attacks in the United States. What is often shown is the massive loss of human lives but the environmental impact of such attacks are usually buried in the rubbles of the news reportage on the loss of lives.

While the above instances are terrorist attacks, a quick look at the response to such attacks may open a Pandora Box. The anti-terror measures are mostly dominated by significant military response which involves the use of cluster bombs to exterminate all traces of terrorists. Beside the collateral damage often experienced during such

24 Schofield, "The Environment as an Ideological Weapon: A Proposal to Criminalize Environmental Terrorism"(1999) 26," 624.

25 Kevin J Fitzgerald, "Chemical Weapons Convention: Inadequate Protection from Chemical Warfare, The," Suffolk Transnat'l L. Rev. 20 (1996): 425.

26 Lockwood, "The Public Health Effects of the Use of Chemical Weapons," 94.

27 "23 Die, Hundreds Injured in Saudi Arabia Explosion," Houston Chronicle News Services, June 25, 1996.

28 Ibid.

29 Ibid. 
anti-terror war, the effect of such military response on the environment is devastating. If such military response is the only way to defeat terrorism, then the world should be prepared for more human casualties and environmental damage as currently being experienced in Syria and Iraq. While one may not exclude wellplanned military response to the threat of terrorism, governments across the world should also think of well-reasoned measures to combat terrorism through non-violent means to ensure more innocent human lives are not lost and less damage is done to the environment.

In 1998, American warplanes attack some sites classified as Bin Laden training camps in Afghanistan, ${ }^{30}$ and El Shifa Pharmaceutical Factory, in Sudan, ${ }^{31}$ which was also suspected to be the main factory for the production and transfer of numerous chemical and gas weapons for terrorist operations. ${ }^{32}$ From the soil samples taken from the factory's ground, the United States got to know that the site was used for producing chemical gases and weapons. ${ }^{33}$ There is no doubt that the attack would have led to great environmental damage, which could not be assessed by any government or international agency. Deadly gases would have been released to the atmosphere which had significant effect on the health of the people. ${ }^{34}$ Similarly, several kinds of military techniques were used in the fight against the Taliban and Al-Qaeda terrorist groups in Afghanistan in October 2001.It is on record that P 52 bombers, which caused collateral damage and massive environmental destruction were used.

Moreover, the Daisy Cutter bomb, weighing 1,500 LB was used over Tora Bora Mountains where it was believed Osama Bin Laden was hidden. ${ }^{35}$ The use of such bomb would have caused

30 Leah Campbell, "Defending against Terrorism: A Legal Analysis of the Decision to Strike Sudan and Afghanistan," Tulane Law Review 74 (2000): 1067-71; Ruth Wedgwood, "Responding to Terrorism: The Strikes against Bin Laden," Yale J. Int'l L. 24 (1999): 566.

31 Campbell, "Defending against Terrorism: A Legal Analysis of the Decision to Strike Sudan and Afghanistan," 1090.

32 Wedgwood, "Responding to Terrorism: The Strikes against Bin Laden," 566.

33 Ibid., 570.

34 Andrew D McClintock, "Law of War: Coalition Attacks on Iraqi Chemical and Biologial Weapon Storage and Production Facilities, The," Emory Int'l L. Rev. 7 (1993): 637-638.

35 Steve Vogel, “'Daisy-Cutter' Dropped on Cave at Tora Bora," Washington Post, December 10, 2001. 
psychological effect, ${ }^{36}$ over the human life in the targeted areas as well as the natural environment. The environmental effects of such weapons would be severe, and will last for decades. The future generations of Afghanistan will suffer from unexploded ammunitions. Few military personnel of the United States were the casualties of the striking back against the terrorists, but the number of Afghan casualties is much greater. The United States lost one of its Central Intelligence Agency (CIA) personnel who was killed in the MazareSharif prison's revolt. ${ }^{37}$ Three more American soldiers were killed and nineteen others were injured by friendly fire, when a 2,000pounds bomb mistakenly targeted their site. ${ }^{38}$ More than 100 Taliban fighters were killed in Mazar-e-Sharif prison revolt. ${ }^{39}$

In counter-terrorism strategies, reprisal actions through military forces should not be the primary choice, because it would harm human lives and the environment as much as it can be harmed by the acts of terror itself. Therefore, in fighting terrorism, there should be some strategic measures to prevent such harmful damages on the environment. A first step may be the need to prevent any impending attack when there is available useful intelligence. Such preventive measures should be the first step in all anti-terror operations. ${ }^{40} \mathrm{~A}$ second step might be the need for the international community to impose economic sanctions on known terrorist organisations and their host countries to serve as a deterrence for others. The international community must fight terrorism by all means, and should not only wait to react after the harm has been unleashed on innocent people and the entire ecosystem.

The environmental impact of terrorist acts, and of course the antiterror war, may have significant implications for the transboundary pollution principle. The next section examines the principle of transboundary pollution prohibition as a main environmental law

\footnotetext{
36

Ibid.

37 Deborah Orin, "CIA HERO'S BODY RETURNS TODAY | New York Post," New York Post, December 2, 2001.

38 Niles Lathem, "BOMB MISTAKE EYED IN GI TRAGEDY | New York Post," New York Post, December 7, 2001.

39 Susan B. Glasser, "100 Taliban Were Killed After Rebels Took Mazar - The Washington Post," Washington Post, November 14, 2001.

40 Ralph Blumenthal, "Tapes Depict Proposal to Thwart Bomb Used in Trade Center Blast - NYTimes.com,” The New York Times, October 28, 1993.
} 
principle which provides the legal bases for the responsibility of terrorists and the harbouring States.

\section{TERRORISM AND THE TRANSBOUNDARY POLLUTION PRINCIPLE}

In every terrorist act, environmental law principles are violated. The September 11 attack on the United States was one of such attacks that had significant impact on the environmental with the severe environmental damages recorded. A significant number of environmental rules deal with the environmental effects of terrorism crimes. The Arab Convention on the Suppression of Terrorism signed at Cairo, Egypt on April 22, 1998, ${ }^{41}$ accords to the environment considerable protection from terrorist attacks, when it provides that terrorism is any act or threat of violence that aims "to cause damage to the environment or to public or private installations or property or to occupy or seize them, or [aim] to jeopardize a national resource." ${ }^{42}$ It also excludes the destruction of public property and public services from being considered as political crimes. ${ }^{43}$ Therefore, any environmental destruction, even if committed for political motives, will be considered as a terrorist offense. ${ }^{44}$

Since the terrorist acts of September 11 and other similar attacks are usually attributed to Islam and Muslims generally, the attitude of the Organisation of Islamic Cooperation has been very impressive. The Islamic Convention on Combating International Terrorism strongly excludes "[the] destruction of public properties and properties geared for public services $[. . .]^{, 45}$ from being considered as political crimes even when politically motivated. Thus, environmental

41 The Arab Convention on the Suppression of Terrorism, Apr. 22, 1998, Cairo, in International Instruments Related to the Prevention and Suppression of International Terrorism(United Nations Publication, 2001) Sales No. E.01.V.3, at 152[hereinafter The Arab Convention on the Suppression of Terrorism].

42 Ibid., art. 1 (2).

43 Ibid., art. 2 (b) (v).

44 Terrorist offense means "[a]ny offense or attempted offense committed in furtherance of a terrorist objective in any of the Contracting States, or against their nationals, property or interests, that punishable by their domestic law." See, Ibid., art. 1 (3).

45 The OIC Convention on Combating International Terrorism, supra note (9) art. 2 (II) (c)(5). 
damage during any act of terrorism is considered a terrorist crime ${ }^{46}$ and is subject to this Convention's provisions. This Convention does not only consider terrorism as constituting a severe violation of human rights and freedom and security, but also considers it as damage to the environment, including the destruction of public properties and public services.

This section focuses only on the violation of the prohibition of the transboundary pollution. The principle of prohibition of transboundary pollution is the main environmental law principle that has been breached by the acts of terrorism. It further explores how the interpretation of the transboundary pollution can be extended to include the terrorist activities under its regime.

The State's obligation to protect other States' right to be aware of any transboundary pollution, including those resulting from acts of terrorism, is an important principle of the environmental law. This principle was elaborated in the Stockholm Declaration, the Rio Declaration and international case law.

\section{Principle 21 of the Stockholm Declaration}

The United Nations Conference on the Human Environment, held in Stockholm on June 16, $1972,{ }^{47}$ adopted a Declaration to protect the environment from any transboundary pollution. It requires nations not to harm the environment of another nation, when it provides that:

States have, in accordance with the Charter of the United Nations and the principles of international law, the sovereign right to exploit their own resources pursuant to their own environmental policies and the responsibility to ensure that activities within their jurisdiction or control do not cause damage to the environment of other states or of areas beyond the limit of national jurisdiction. ${ }^{48}$

The above principle recognises the right of each State, to capitalise on its resources without any form of interference from another nation, including hosting any activities on their territories.

46 For the purposes of the Convention, terrorist crime means "any crime executed, started or participated in to realize a terrorist objective in any of the Contracting States or against its nationals, assets or interests or foreign facilities and nationals residing in its territory punishable by its internal law." See, The OIC Convention on Combating International Terrorism, Art. 1 (3).

47 Declaration of the United Nations Conference on the Human Environment, U.N.Doc. A/Conf. 48/14 Stockholm, (1972)

48 Id., Principle 21. 
However, the restriction to this right is seen in a state's mandatory not to harm the environment of another state, including not allowing territories under its control to do so. ${ }^{49}$ This principle is confirmed in the Rio Declaration.

\title{
Principle 2 of the Rio Declaration
}

During the twentieth anniversary of the Stockholm Conference in 1992 Rio de Janeiro, Brazil, the "Earth Summit" was sponsored by the United Nations in in. The Rio Declaration on Environment and Development, the Climate Change Convention, the Declaration of "non-binding" Principles on Forest Conservation, the Convention on Biological Diversity, and Agenda 21 were all adopted during the summit.

It is interesting to note that Principle 2 of the Rio Declaration on the Transboundary environmental damage is very identical to Principle 21 of the Stockholm Declaration. ${ }^{50}$ It provides that:

\begin{abstract}
States have, in accordance with the Charter of the United Nations and the principles of international law, the sovereign right to exploit their own resources pursuant to their own environmental and developmental policies, and the responsibility to ensure that activities within their jurisdiction or control do not cause damage to the environment of other states or of areas beyond the limits of national jurisdiction. ${ }^{51}$
\end{abstract}

Establishing training camps in Afghanistan to train some Islamic groups does not interfere with the content of Principle 21. But starting from the moment that training activities harm other nation's environment, by planning, training, financing, directing and celebrating acts of terrorism against other nations territory, then the responsibility for damages, including the environmental damage, may arise. It would be useful to confirm that harm may occur through effective terrorist activities as well as a threat of committing such activities.

49 Aaron Schwabach, "Environmental Damage Resulting from the NATO Military Action Against Yugoslavia," Columbia Journal of Environmental Law 25 (2000): 117.

50 United Nations Conference on Environment and Development, U.N. Doc. A/Conf. 15/26, vol. I Rio, (1992).

51 Ibid., Principle 2. 
Despite the inclusion of Principle 21 of the Stockholm Declaration and Principle 2 of the Rio Declaration in non-mandatory instruments (declarations), their content generally restates the general principles of international law, and such general principles are binding on all States.

\section{International Case Law}

The Trail Smelter Case gave birth to the responsibility for transboundary pollution principle. ${ }^{52}$ This principle has been widely accepted as part of customary international law which is generally applied to cases involving pollution through different means which might not be through the air. ${ }^{53}$ In this leading case, the Court held inter alia that under the principles of international law "no State has the right to use or permit the use of territory in such a manner as to cause injury by fumes in or to the territory of another or the properties or persons therein." ${ }^{54}$ This obligation was reaffirmed by the International Court of Justice in the Corfu Channel Case. ${ }^{55}$ In this second case, the Court held that it is "every State's obligation not to knowingly allow its territory to be used for acts contrary to the rights of other States." Declaration incorporated the Corfu Channel standard, when respectively Principle 21 and Principle 2 prohibit States from allowing their territories to be used for such acts that are contrary to the rights of other States. ${ }^{57}$

The Taliban harbouring of the Al-Qaeda camps, offering them the protection and support, and refusing to destroy theirs camps is violation to the rules of law that were established by the precedents case law. These legal bases will hold any source State responsible for environmental damage that crosses its borders and harms the

52 Trail Smelter, (U.S. v. Canada), 3 R.I.A.A. 1911, 1965 (Apr. 16, 1938 \& Mar. 11, 1941)

532 Restatement (Third) of the Foreign Relations of Law of the United States $\S$ 601 reps. Note 1 (1987).

54 Trail Smelter's case, at 1965.

55 Corfu Channel Case, UK v. Alb," accessed December 19, 2015, http://www.icjcij.org/scripts/view.php?c=1\&f=1653\&k=254ae0ee64cd2210d19bc7fd0261e386 \&lang=en.

56 Ibid., 22.

57 Stockholm Declaration, Principle 21. 
environment of other nations. ${ }^{58}$ The recent ISIL crises in Syria and Iraq where there are allegations of instances of state-sponsored terrorism also violate such international law principles.

\section{ENVIRONMENTAL DEGRADATION AND RESPONSIBILITY FOR ACTS OF TERRORISM}

Causing environmental pollution to other nation's environment, in contradiction to the prohibition of transboundary pollution principle can provide a legal basis for addressing State's responsibility. Environmental damage resulting from acts of terrorism can raise two kinds of responsibilities: international responsibility of the State, and criminal responsibility of the terrorists. The application of the transboundary pollution over terrorist activities will enlarge the domain of the actual system of responsibility to include terrorism as a kind of pollution.

\section{The State Responsibility for Transboundary Pollution through Terrorism}

International responsibility of the State is based on the State's fault, which is called fault responsibility; and could also stand without fault, which may be called strict or absolute liability.

\section{Fault Responsibility}

In terrorist crimes four patterns of fault can be attributed to a State in view to be held responsible for humanitarian and environmental effects of terrorism:

(1) Harbouring the Terrorism Against the State's Will

Terrorist activities can take place in a State territory and against the State's will. Terrorist may use the State's territory to train and conduct researches to produce weapons of mass destruction, in order to harm other nation's environment. In this case, the harbouring State will not be held internationally responsible unless it opposes the international efforts to fight the terrorism. Otherwise, if it fights the

58 Teresa A Berwick, "Responsibility and Liability for Environmental Damage: A Roadmap for International Environmental Regimes," Geo. Int'l Envtl. L. Rev. 10 (1997): 257. 
terrorists and facilitates the international community's mission in fighting the terror, by allowing the use of its territory and military bases, providing military, economic and financial contributions to fight the terror, then there will be no legal stand for its international responsibility.

(2) Unintentional and Negligent Harbouring of Terrorists in one's States

Some countries know that there are terrorists in their territories but fail to combat them.. Here, the negligence is considered a legal basis for State's responsibility. An example of negligence is the United States' attitude prior to the September 11 attacks. The Unites States administration has received serious threats, and was subject to a much less dangerous terrorist attacks from Al-Qaeda, but did not take it seriously, and was satisfied with attacking two sites in Afghanistan and Sudan in $1998 .^{59}$ Here, the State can be held responsible for its negligence, since it could have arrested the terrorists but it did not take it seriously, until the terrorists find a good time and place to commit their crimes. In this case, the negligence of the State stands behind the terrorist attack.

\section{(3) State's Passive Assistance to Terrorist Activities}

Unfortunately, some States know that terrorist groups are based in their territory, training, or conducting researches to produce arms of mass destruction, but they are passive, and look the other way. In the occurrence case, the passive attitude of the State should be considered as a fault, and the State's responsibility is based on the fact that, at a certain time, it was able to stop or eliminate the risk of terrorist activities, but its unintentional negligence prepared the climate and the suitable circumstances for the terrorists to commit their crime.

Here, the State can be responsible for its passivism, since it turns the other way and indirectly nourish terrorism and provide it with all the needs to live and spread out all over the globe. Despite the passive attitude that holds these States internationally responsible, States can avoid such responsibility by cooperating with the international community to arrest the perpetrators and bring them to justice. For example, after the September 11, Kuwait avoided such responsibility by joining the international efforts in fighting the terrorism, where

59 Campbell, at 1089-90. 
suspected accounts were frozen in Kuwait, intelligent information were shared with the concerned States, ${ }^{60}$ the citizenship of the so called Al-Qaeda Spokesman, Suleiman Abu-Ghaith, was withdrawn, ${ }^{61}$ and a number of young Kuwaitis were prevented from travelling to Afghanistan, detained and investigated.

(4) Deliberately Harbouring the Terrorists:

Harbouring the terrorists is a new term that has been used, after the September 11 attack by the former American President Bush. ${ }^{62}$ It became a frequent international law term. When States deliberately harbour terrorism, help and hide them, they can be held responsible for such acts, because it violates the rules of international law regarding the fight against terrorism. In such situations, the State is internationally responsible, and its responsibility is considered alongside with the terrorists' responsibility. Despite this responsibility, the State may reduce its international responsibility, and begin a new era, by joining the international community's efforts in the fight against terrorism.

\section{Absolute Responsibility}

It is time to ensure peace prevails all over the world. Peace cannot prevail without holding each State responsible for the activities that are perpetuated under its jurisdiction, whether legal or illegal. Acts of force committed within a nation's territory from its own citizens should not be subject to international responsibility. For example, terrorist activities committed by the Spain separatists group; as long as it does not harm other nation's interests, citizens or the environment, should not be subject to the international efforts to fight the terrorism. This kind of activity should be subject to the internal laws of the State, and other States should not intervene in the internal affairs of the State. Other States can intervene only if such activities were expanded beyond the States borders or threats other nations'

60 "The Government Activates the Supervision over the Charity Accounts, and Decide to Deal Positively with the American Demands," Arai Alaam Newspaper, September 9, 2001, 1.

61 "The Council of Ministers Decided to Withdraw Abu-Ghaith Citizenship," ALWATAN Newspaper, October 15, 2001.

62 This concept was frequently used by the American President and his Cabinet during the period of time that followed the Sept. 11, 2001, attacks on the United States. 
interests, citizens, or environment. The terrorist activities of Al-Qaeda did not present a legal basis for international military action against Afghanistan. International military action was only necessary when such activities harmed other nations interests, and environment. On the other hand, the dastard terrorist activities of ISIL in Syria and Iraq has an international dimension and requires concerted efforts at the international level to stem the rising tide of terrorism.

Principle 21 of the Stockholm and Principle 2 of the Rio are general about the source of activity that cause transboundary pollution, so it can be illegal and legal as well. The absolute responsibility is a great basis to eliminate the confrontation between different ideologies regarding what can be considered as terrorist act that held States responsible and the heroic acts that are considered as the right of a State. In both cases, since terrorist acts damage other nation's environment, the State that is the source of these acts should be held internationally responsible, because it could not prevent such acts from harming other nations humans and environment.

For example, without discussing the issue of Palestinian right of self-determination, and oppose the occupation, the Organization of Liberation Palestine (OLP), as a legal representative of the Palestinians, should be held responsible for acts committed against Israel, even if they claim that they are practicing the right of selfdetermination, because diplomacy is the only way of resolving international questions. Act of force should be limited within the territories supervised by the OLP, and only the diplomacy should be shown beyond these territories.

Similarly, since certain proves pointing that most of the terrorists of September $11^{\text {th }}$ were trained in Afghanistan, then the acts committed in Afghanistan (training) under any legal or illegal pretext, harmed other nation's environment, such as the United States of America, is enough element to hold the Afghani government internationally responsible for the transboundary pollution.

As a result of the responsibility, State may be subject to international sanctions, whether imposed by international organisation or the coalition of States. The international community may mount pressure on the responsible State by imposing international sanctions, military action, and finally may require restitution, rehabilitation, and compensation. 


\section{The Criminal Responsibility of the Terrorists}

The terrorists can be subject to criminal responsibility within the international legal system as well as the internal or domestic legal system.

\section{International Criminal Responsibility}

International criminal rules can be applied against terrorists whenever they commit a crime that has international characters in violation of international instruments such as attacking an international organisation's building, using unlawful techniques and methods of war, attacking civilians and civil objects, destroying internationally protected sites and monuments. These acts can be classified in international law as war crimes, crimes against peace, or crimes against the humanity. ${ }^{63}$ The international community must cooperate

63 Article 5 of the ICTY and 3 of the ICTR provide that the Tribunals shall have the power to prosecute persons responsible for the following crimes "[...] (a) murder; (b) extermination; (c) enslavement; (d) deportation; (e) imprisonment; (f) torture; (g) rape; (h) persecutions on political, racial and religious grounds; (i) other inhumane acts." S.C. Res. 808, U.N. SCOR, 48th Sess., 3175th mtg. at 28, U.N. Doc. S/INF/49 (1993) [hereinafter ICTY Statute]; S.C. Res. 955, U.N. SCOR, 49th Sess., 3453rd mtg. at 2, U.N. Doc. S/RES/955 (1994) [hereinafter ICTR Statute]. Article $7 \& 8$ of the ICC Statutes provide that " [...] crime against humanity means any of the following acts when committed as part of a widespread or systematic attack directed against any civilian population, with knowledge of the attack: (a) Murder; (b) Extermination; [...] 2. For the purpose of paragraph 1: (a) "Attack directed against any civilian population" means a course of conduct involving the multiple commission of acts referred to in paragraph 1 against any civilian population, pursuant to or in furtherance of a State or organizational policy to commit such attack; $[\ldots]$ " "[...] war crimes means: (a) Grave breaches of the Geneva Conventions of 12 August 1949, namely, any of the following acts against persons or property protected under the provisions of the relevant Geneva Convention: (i) Willful killing; [...] (iii) Willfully causing great suffering, or serious injury to body or health; (iv) Extensive destruction and appropriation of property, not justified by military necessity and carried out unlawfully and wantonly; (viii) Taking of hostages. (b) Other serious violations of the laws and customs applicable in international armed conflict, within the established framework of international law, namely, any of the following acts: (i) Intentionally directing attacks against the civilian population as such or against individual civilians not taking direct part in hostilities; (ii) Intentionally directing attacks against civilian objects, that is, 
to respond to such terrorist acts, by considering such acts as war crimes. Such crimes must not be treated as mere domestic crimes within the national criminal jurisdictions of a country. ${ }^{64}$ It is war crime whether committed in peace time or in times of armed conflict, because even if it is committed in peacetime it is an act of war and would necessarily lead to an armed conflict.

When war crimes have been committed, the perpetrators must be submitted to the jurisdiction of ad hoc or permanent international

objects which are not military objectives; (iii) Intentionally directing attacks against personnel, installations, material, units or vehicles involved in a humanitarian assistance or peacekeeping mission in accordance with the Charter of the United Nations, as long as they are entitled to the protection given to civilians or civilian objects under the international law of armed conflict; (iv) Intentionally launching an attack in the knowledge that such attack will cause incidental loss of life or injury to civilians or damage to civilian objects or widespread, long-term and severe damage to the natural environment which would be clearly excessive in relation to the concrete and direct overall military advantage anticipated; (v) Attacking or bombarding, by whatever means, towns, villages, dwellings or buildings which are undefended and which are not military objectives; [...] (ix) Intentionally directing attacks against buildings dedicated to religion, education, art, science or charitable purposes, historic monuments, hospitals and places where the sick and wounded are collected, provided they are not military objectives; (xiii) Destroying or seizing the enemy's property unless such destruction or seizure be imperatively demanded by the necessities of war; [...] (xvii) Employing poison or poisoned weapons; (xviii) Employing asphyxiating, poisonous or other gases, and all analogous liquids, materials or devices; (xx) Employing weapons, projectiles and material and methods of warfare which are of a nature to cause superfluous injury or unnecessary suffering or which are inherently indiscriminate in violation of the international law of armed conflict, provided that such weapons, projectiles and material and methods of warfare are the subject of a comprehensive prohibition and are included in an annex to this Statute, by an amendment in accordance with the relevant provisions set forth in articles 121 and 123; [...] (e) Other serious violations of the laws and customs applicable in armed conflicts not of an international character, within the established framework of international law, namely, any of the following acts: (i) Intentionally directing attacks against the civilian population as such or against individual civilians not taking direct part in hostilities; [...]"Rome Statute of the International Criminal Court, arts. $7 \& 8$ (1998) 37 I.L.M. 999 (1998).

64 Spencer J Crona and Neal A Richardson, "Justice for War Criminals of Invisible Armies: A New Legal and Military Approach to Terrorism," Okla. City UL Rev. 21 (1996): 349. 
tribunals. At present, there is no ad hoc tribunal that has jurisdiction over terrorist activities committed against a State. But there is no legal obstacle to establish one by the United Nations Security Council, to prosecute the suspected terrorists according to the law of war, and to avoid any request of different governments to prosecute their citizens involved in different terrorist activities.

Despite the absence of such ad hoc tribunal, the International Criminal Court (ICC) has the competent jurisdiction to prosecute crimes of war. ${ }^{65}$ However, the dilemma here is that some developed countries such as the United States isyet to ratify the Statute of the ICC. The Statute of the ICC excludes the right of the court to examine questions involving non-member States.

From the previous examination of terrorism, the international character of terrorism is more pronounced, which gradually excludes the national jurisdiction of any State from examining such matter. Practically, States who experience acts of terrorism react based on their national security and protection of their respective nations, and give themselves the priority right to prosecute and punish the perpetrators according to their national jurisdictions.

\section{Internal Criminal Responsibility}

The internal criminal responsibility of a terrorist can be argued by his State, States supporting the terrorist, or by the State who claim jurisdiction over his prosecution. It is agreed that no State should protect terrorists, even if they are its citizens, in order to prevent terrorists from finding safety in "sympathetic States" that are unwilling to prosecute them despite the international pressure. ${ }^{66}$ The difference between States' legal systems may reflect on the terrorist conviction and the nature of his punishment, where he might be freed or convicted in a symbolic punishment. In contrast, under the pressure of being a victim of an act of terrorism, the State may ignore the terrorist's rights provided in its national legal system, prosecute him outside the ambit of its judicial system, or punish him without prosecution. Therefore, such crimes should be submitted to an international jurisdiction, prosecuted publicly under the rules of the

\footnotetext{
65 Rome Statute, supra note (155) art. 8.

66 Wallace F Warriner, "The Unilateral Use of Coercion Under International Law: A Legal Analysis of the United States Raid on Libya on April 14," Naval L. Rev. 37 (1986): 49-67.
} 
international law, while assuring all that the right to fair hearing will be upheld.

\section{CONCLUSION: AVOIDING FUTURE ENVIRONMENTAL EFFECTS OF TERRORISM}

It has been established in this study that terrorism, and even counterterrorism measures, do have devastating effects on the environment. It is true all hands must be on deck to stem the rising tide of terrorism; but one must ask further that at what cost? How do we prevent collateral damage which does not only refer to human lives but the entire ecosystem? A victim State may be compelled to use military force to fight terror but does such a state considers the environmental impact of such anti-terror war on the innocent people and the environment? In response to these, the United Nations need to brace up and supervise every counter-terror measures through its Security Council. The UN military forces can be used to supervise such measures in order to prevent massive degradation of the environment in counter-terror measures. This may require a special body under the UN which will bring together environmental experts and counterterror specialists to work together to ensure the environment remains protected and collateral damage is prevented by all means.

On the part of the terrorists, there is a need for the international community to send a clear message to them, that the clear message must emphasise the significance of the environment as well as the civil personnel and properties. The continuous attacks on these will mount up pressure on them from all angles to suppress their terrorist tendencies. However, states, as members of the international community, should be bound by the international and humanitarian rules protecting humans and the environment. Any act of reaction against terrorism should be taken in a safe and environmentally sound way. Human casualties and environmental destruction should be minimised and avoid. In essence, international efforts in fighting the terrorism should be well organised and coordinated. 